\title{
ANALISIS SWOT PELAKSANAAN PROGRAM ONE VILLAGE ONE PRODUCT (OVOP) PADA KOPERASI MITRA TANI PARAHYANGAN CIANJUR
}

\author{
Zainal Arifin H Masri \\ Program Studi Pendidikan Ekonomi, FIPPS \\ Universitas Indraprasta PGRI \\ email: zarifin243@yahoo.com.
}

Diterima: Februari 2018; Disetujui: Maret 2018; dipublikasikan: April 2018

\begin{abstract}
ABSTRAK
Penelitian ini dilakukan di Koperasi Mitra Tani Parahyangan, Desa Tegalega, Kecamatan Warungkondang, Kabupaten Cianjur. Penelitian dilakukan di daerah dengan pertimbangan sebagai berikut: Pertama, adanya kemungkinan masalah yang akan diselidiki; Kedua, adalah produsen dan breeder agribisnis hortikultura terbaik di Jawa Barat; Ketiga, salah satu proyek percontohan keberhasilan pelaksanaan OVOP di Jawa Barat, banyak menerima penghargaan nasional dan memiliki jaringan pasar yang kuat dengan gerai mitra yang tersebar di JABODETABEK. Penelitian ini bertujuan untuk: (1) mendeskripsikan pelaksanaan program One Village One Product (OVOP) yang dilaksanakan di Koperasi Mitra Tani Parahyangan Cianjur, (2) untuk mendeskripsikan faktor Kekuatan, Kelemahan, Peluang dan Ancaman (ancaman), yaitu di Koperasi Mitra Tani Parahyangan Cianjur (3) untuk menganalisis strategi pengembangan yang diterapkan oleh Koperasi Mitra Tani Parahyangan Cianjur dalam menjalankan program One Village One Product (OVOP). Untuk tujuan pertama dan kedua dari penelitian ini, kami menggunakan metode studi kasus dengan analisis deskriptif kualitatif untuk menggambarkan implementasi program One Village One Product (OVOP) yang dilaksanakan di Koperasi Mitra Tani Parahyangan Cianjur, dan Kekuatan, Kelemahan, Peluang yang ada, dan faktor Ancaman. Untuk tujuan ketiga menganalisis strategi pengembangan yang diterapkan oleh Koperasi Mitra Tani Parahyangan dalam mendukung program One Village One Product (OVOP) menggunakan analisis SWOT
\end{abstract}

Kata kunci: OVOP, studi kasus, deskriptif kualitatif, analisis SWOT.

\begin{abstract}
This research was conducted at Cooperative Mitra Tani Parahyangan, Tegalega Village, Warungkondang Sub-district, Cianjur District. The study was carried out in the area with the following considerations: First, the existence of possible problems to be investigated; Second, is the best producer and breeder of Horticulture Agribusiness in West Java; Third, one of the pilot projects of the successful implementation of OVOP in West Java, many received national awards and has a strong market network with partners outlets spread across JABODETABEK. This study aims to: (1) describe the implementation of the One Village One Product (OVOP) program implemented in Cooperative Mitra Tani Parahyangan Cianjur, (2) to describe the factors of Strengths, Weakness, Opportunities and Threats (threat), which is in Cooperative Mitra Tani Parahyangan Cianjur (3) to analyze development strategy applied by Cooperative Mitra Tani Parahyangan Cianjur in running One Village One Product (OVOP) program. For the first and second objectives of this study, we used a case study method with qualitative descriptive analysis to describe the implementation of One Village One Product (OVOP) program implemented in Cooperative Mitra Tani Parahyangan Cianjur, and the existing Strengths, Weakness, Opportunities, and Threats factors. For the third purpose of analyzing development strategy applied by Cooperative Mitra Tani Parahyangan in supporting One Village One Product (OVOP) program used SWOT analysis
\end{abstract}

Keywords: OVOP, case study, qualitative descriptive, SWOT analysis 


\section{PENDAHULUAN}

Indonesia mayoritas penduduknya berada di daerah pedesaan dengan sebagaian besar penduduk menggantungkan hidupnya pada sektor pertanian. Dimana penggunaan lahan di Indonesia sebagian besar diperuntukkan sebagai lahan pertanian (Husodo, 2004:23). Dengan demikian kebijakan pembangunan yang paling tepat dilakukan yakni pembangunan pedesaan (rural development) atau berkaitan dengan pembangunan pertanian. Kegiatan usaha tani di pedesaan dalam suatu sistem agribisnis pada umumnya meliputi penyediaan sarana produksi pertanian (benih, pupuk, pemberantasan hama penyakit, alat-alat pertanian), penyediaan modal, pemenuhan tenaga kerja, kegiatan usaha tani/bercocock tanan (on farm), penyediaan informasi dan teknologi, pengolahan pasca panen dan pemasasaran hasil produksi (Syahyuti, 2008).

Salah satu program pembangunan yang dikembangkan di Indonesia adalah Program One Village One Product (OVOP). Di Indonesia program OVOP mulai dilaksankan pada tahun 2008 oleh Kementerian Koperasi dan UKM. Salah satunya diterapkan di Koperasi Mitra tani Parahyangan (KMTP) di desa Tegalega kecamatan Warungkondang Cianjur dengan fokus pengembangan usaha Agribisnis Hortikultura. KMTP yang terbentuk pada tahun 2000 ini telah berhasil menembus pasar swalayan dan melaksanakan trading dengan 120 outlet ternama, seperti Giant Supermarket, Lion Superindo, Bellfood, Alfamidi, dan sejumlah outlet lainnya. Inilah yang membuat KMTP dipercaya untuk melaksanakan program One Village One Product (OVOP) binaan Kementerian Koperasi dan UKM.

Petani dan masyarakat pedesaan lainnya sering kali hanya dijadikan alat untuk menjalankan proyek-proyek pemerintah/kementerian. Bukan sebagai upaya untuk meningkatkan pemberdayaan masyarakat pedesaan. Kebijakan yang bersifat top-down/dari atas kebawah yakni dari pemerintah pusat ke daerah/desa menyebabkan partisipasi masyarakat tidak tumbuh (Kedi Suradisastra, 2008). Salah satu strategi pemerintah dalam mengatasi permasalahan tersebut yakni dengan melaksanakan program One Village One Product (OVOP), dengan adanya program OVOP ini diharapkan kelompok masyarakat lebih mandiri dan tentunya berpengaruh terhadap pendapatan dan kesejahteraan kelompok masyakat tersebut.

Berdasarkan uraian diatas, maka dirasa perlu untuk melakukan penelitian ini, maka rumusan masalah dalam penelitian ini adalah ; 1) Bagaimana pelaksanaan program One Village One Product (OVOP) yang diterapkan di KMTP, 2) Apa faktor-faktor kekuatan, kelemahan, peluang dan ancaman (kekepan) yang dimiliki/terdapat di KMTP, 3) Bagaimana strategi pengembangan yang diterapkan KMTP Cianjur dalam mendukung program One Village One Product (OVOP).

Berdasarkan latar belakang pemikiran dan perumusan masalah di atas, maka penelitian ini dilakukan dengan tujuan sebagai berikut : a) Mendeskripsikan pelaksanaan program One Village One Product (OVOP) yang diterapkan di Koperasi MTP, b) Mendeskripsikan kekuatan, kelemahan, peluang dan ancaman yang ada/terdapat di Koperasi Mitra Tani Parahyangan Cianjur, c) Menganalisis strategi pengembangan yang direpkan KMTP Cianjur dalam mendukung program One Village One Product (OVOP).

\section{METODE}

Dalam penelitian ini metode yang digunakan peneliti adalah studi kasus (case study).. Teknik pengambilan sampel dilakukan secara sensus yaitu semua petani yang termasuk kedalam kelompok tani MTP. Penentuan sampel dalam penelitian ini dilakukan dengan menggunakan Probability Sampling dengan teknik Stratifed Random Sampling, penggunaan metode ini dimaksudkan agar sampel yang didapat bisa mewakili karakteristik dalam populasi yang berstrata (tidak sama) dengan kata lain adanya kelas-kelas tertentu.

Teknik yang digunakan dalam menentukan besarnya sampel salah satunya dengan 
Volume 10, No. 1, April 2018, pp. 47-56

e-ISSN: $2502-5449$

p-ISSN: 2085-2266

http://journal.lppmunindra.ac.id/index.php/sosio_ekons

menggunakan cara Slovin. Menurut Umar (2008:108) menerangkan bahwa untuk

menghitung besarnya ukuran sampel dapat dilakukan dengan menggunakan rumus Slovin :

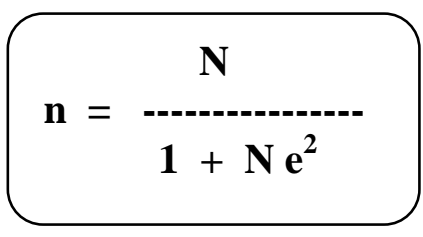

Dimana :

$\mathrm{n}=$ ukuran sampel, $\mathrm{N}=$ ukuran populasi $=329, \mathrm{e}=$ taraf kesalahan $=0,1$, maka

$$
\begin{gathered}
\mathrm{N} \\
\mathbf{n}=\mathbf{1}+\mathrm{N} \mathrm{e}^{2} \\
\hdashline 1+329(0,1)^{2}
\end{gathered}
$$

Data yang dikumpulkan dalam penelitian ini meliputi data primer dan data sekunder. Data primer diperoleh melalui wawancara langsung dengan informan kunci (key informan) secara mendalam dengan bantuan pengisian daftar pertanyaan (kuisioner) yang telah disiapkan sebelumnya yang berhubungan dengan penelitian ini untuk kelompok tani MTP. Sedangkan data sekunder yang dibutuhkan diperoleh dari lembaga atau instansi yang berhubungan dengan penelitian ini seperti dinas pertanian, BPP (Balai Penyuluh Pertanian), serta literatur-literatur yang relevan seperti buku-buku, jurnal penelitian internet dan laporan-laporan yang berhubungan dengan penelitian ini.

Analisis data untuk tujuan pertama digunakan analisa deskriptif kualitatif yang memberikan gambaran produk unggulan daerah yang potensial, peran Koperasi MTP, akses pasar produk yang dihasilkan melalui temu usaha serta promosi produk secara lokal, nasional dan internasional, kapasitas SDM melalui pembinaan, penyuluhan, pelatihan dan studi banding. Untuk tujuan kedua digunakan analisis deskriptif kualitatif yaitu mendeskripsikan faktor internal yakni kekuatan dan kelemahan yang dimiliki KMTP dan faktor eksternal yakni peluang dan dan ancaman yang datangnya dari luar KMTP.

Untuk tujuan ketiga yaitu menganalisis strategi pengembangan KMTP dalam melaksanakan program One Village One Product (OVOP) digunakan analisa SWOT. Analisa SWOT yang memuat variabel faktor internal yang meliputi aspek yang menjadi kekuatan dan kelemahan, serta variabel faktor eksternal yang meliputi aspek yang menjadi peluang dan ancaman. Faktor-faktor internal dan eksternal yang ditemukan kemudian diberi bobot dan rating untuk kemudian dihitung skore yang diperoleh dan ditentukan kordinat organisasi.

\section{HASIL DAN PEMBAHASAN}

Program OVOP yang dilaksanakan di KMTP Tegalega-Warungkondang, Cianjur merupakan kegiatan agribisnis hortikultura. Kegiatan agribisnis hortikultura merupakan kegiatan usaha yang sudah menjadi tradisi masyarakat setempat (penuturan Yayat Duriat, 26 Juli 2017). Program OVOP yang dilaksanakan di KMTP dibawah binaan Kementerian Negara Koperasi dan UKM. Pihak Kemeneg Koperasi dan UKM mengarahkan pengurus KMTP untuk merancang proposal bantuan dana usaha. Kerjasama tersebut berlanjut sampai pada bantuan 


\section{sosio e-kons}

Volume 10, No. 1, April 2018, pp. 47-56

e-ISSN: 2502-5449

p-ISSN: 2085-2266

http://journal.lppmunindra.ac.id/index.php/sosio_ekons

dana penangkaran benih sebesar Rp 78.200.000,- diberikan kepada KMTP pada tahun 2002.

Selanjutnya pada tahun 2004 KMTP sudah mampu memasarkan produk kesejumlah pasar swalayan yang ada diwilayah Jabodetabek, yang akhirnya mengalami peningkatan hingga saat ini. Kesuksesan tersebut kemudian oleh Kementerian Negara Koperasi dan UKM menawarkan program OVOP kepada KMTP dan tanpa pikir panjang pengurus KMTP dapat menerimanya dengan nama OVOP Agribisnis Hortikultura. Keputusan mengambil posisi dibidang agribisnis hortikultura ini didasarkan pada kriteria usaha dari waktu kewaktu dan hasil-hasil penelitian terdahulu, menunjukan bahwa daerah Cianjur sangat baik dan cocok untuk dipilih sebagai pelaksana program OVOP dengan produk unggulan agribisnis hortikultura yang ada di kecamatan Warungkondang yang pelaksanaannya dilakukan di KMTP. Kegiatan usaha agribisnis hortilulturan yang dijalankan oleh KMTP, ternyata mengalami masalah dalam distribusi produk, yaitu produknya layu, busuk didalam kendaraan pengangkut sayur mayur. melihat permasalahan ini, pihak KMTP meminta diberikan satu unit cool storage untuk mengurangi rejeksi sebesar $25 \%$ setiap harinya.

Pada akhir tahun 2008, pihak Kementerian Negara Koperasi dan UKM mengabulkan permintaan pihak KMTP untuk memberikan satu unit cooling mobile yang kegunaannya untuk mereduksi resiko layu dan rusak diperjalanan. Upaya untuk terus mengembangkan OVOP juga dari pemberian dana oleh Kementrian Negara Koperasi dan UKM untuk merintis usaha kompos organik ditahun 2009. Kerjasama dalam pengembangan program OVOP ternyata tidak hanya berhenti begitu saja, ditahun 2010, pemerintah juga memberikan bantuan pembuatan greend house budidaya paprika.

Unit Usaha Otonom (UUO) Hortikultura terus memainkan perannya bersama anggota KMTP dalam proses produksi. Anggota KMTP menanam beberapa jenis komoditi sayuran seperti tomat, sawi putih, buncis, brokoli, terong panjang ungu, ketimun dan kapri. Produk sayuran yang menjadi unggulan antara lain, tomat dan kapri karena permintaan akan komoditas tersebut cukup tinggi. Selain tomat dan kapri yang menjadi produk unggulam, saat ini juga sedang dikembangkan paprika jenis warna hijau dan paprika warna merah. Kecendrungan anggota KMTP memilih paprika hijau dan merah, karena masa panennya lebih cepat. Komoditas paprika merupakan yang terbaru untuk dieksploitasi hasilnya. KMTP setiap harinya mampu memasarakan sekitar 2,5 ton per hari berbagai komoditas hortikultura ke wilayah Jabodetabek.

\section{Peran Koperasi Mitra Tani Parahyangan}

Petani yang sudah menjadi anggota KMTP, otomatis dapat melaku kan kerjasama dan mendapatkan fasilitas yang diberikan oleh KMTP. Terdapat beberapa mekanisme atau tata cara dalam pemberian fasilitas KMTP kepada petani anggotanya antara lain mekanisme bantuan permodalan, mekanisme bantuan pembinaan dalam proses budidaya dan mekanisme hasil panen dan sistem pembayaran.

Pemberian bantuan modal yang diberikan kepada petani anggota dengan dua sistem, pertama berupa sarana dan prasarana produksi seperti benih, pupuk dan pestisida. Kedua dalam bentuk uang yang dapat digunakan petani untuk membeli sendiri keperluan sarana dan prasarana produksi atau digunakan untuk pembayaran tenaga kerja. Jaminan untuk mendapatkan bantuan modal dari KMTP hanya berupa tanda keanggotaan KMTP saja, tidak terdapat kontrak kerjasama tertulis antara KMTP kepada petani anggota. Prinsip keterbukaan dan kejujuran coba diterapkan oleh KMTP guna menumbuhkan sikap komitmen dan kekompakan antara petani anggota dan KMTP.

Bantuan permodalan yang diberikan kepada anggota adalah berupa pinjaman yang akan disesuaikan dengan harga benih, pupuk dan pestisida. Bantuan modal berupa sarana dan prasarana produksi akan diberikan jika petani anggota membutuhkan bantuan modal tersebut. Petani yang menerima bantuan modal dari KMTP untuk usahataninya, maka hasil panen harus dijual ke KMTP. Uang hasil penjualan tomat dari hasil panen akan dipotong sebesar biaya pinjaman. Pemotongan dari hasil panen dilakukan pihak KMTP sehingga petani akan langsung 
menerima pendapatan bersih setelah dipotong biaya pinjaman. Pihak KMTP memberikan kebijakan dalam pelunasan pinjaman bisa dilakukan secara bertahap apabila terjadi gagal panen.

Kegagalan dalam panen bisa saja terjadi dalam usahatani. Penyebab gagal panen dapat berasal dari berbagai hal diantaranya karena serangan hama dan penyakit, kondisi cuaca yang tidak menentu atau karena perlakuan terhadap tanaman yang tidak maksimal. Risiko kegagalan yang dapat terjadi dalam usahatani sepenuhnya ditanggung oleh petani anggota, namun dengan adanya komunikasi dan konsultasi proses produksi yang intensif dan berkesinambungan risiko tersebut dapat dikurangi. Petani yang sudah menjadi anggota KMTP, sebelum melaksanakan usahataninya, telebih dahulu akan memperoleh pelatihan dari P4S KMTP (Pusat Pelatihan Pertanian Pedesaan dan Swadaya KMTP). Dalam pelatihan ini, petani akan mendapat penjelasan tentang cara budidaya yang baik, cara mengatasi hama dan penyakit serta hal-hal yang terkait dengan usahatani. Sehingga diharapkan dapat memeperolah hasil panen yang optimal. KMTP memberikan bantuan budidaya melalui penyuluh pertanian setempat. Untuk petani anggota yang berada di sekitar lokasi KMTP akan lebih sering bertemu langsung dengan pihak penyuluh pertanian setempat, dapat melakukan konsultasi terhadap masalah yang dihadapi dalam usahataninya. Sedangkan untuk petani anggota yang lokasinya jauh dari KMTP bisa melakukan konsultasi terhadap permasalahan yang terjadi melalui telepon genggam.

Sistem pembayaran hasil panen yang diterapkan KMTP dilakukan dengan dua cara, pertama pembayaran dilakukan dua minggu setelah produk (hasil panen) diterima, sistem ini berlaku untuk petani yang sudah memiliki cukup modal untuk penanaman berikutnya. Hal ini dilakukan untuk menyesuaikan dari pembayaran yang dilakukan oleh pasar swalayan kepada KMTP. Sedangkan sistem pembayaran yang kedua adalah pembayaran langsung tunai untuk setengah dari nilai produk (hasil panen) yang diterima koperasi.

Secara umum peran KMTP menekankan pada hubungan pemasaran terhadap produk usahatani yang dihasilkan. KMTP akan melakukan prediksi komoditas apa yang dibutuhkan konsumen dalam periode tertentu berdasarkan informasi pasar yang diperoleh. Dari hasil prediksi tersebut, KMTP akan memberikan saran kepada petani anggota untuk menanam komoditas yang dibutuhkan. Selama proses produksi petani mitra akan menerima bimbingan teknis budidaya yang baik dan konsultasi penanganan hama dan penyakit. Untuk komoditas tomat yang harus dijual kembali ke MTP adalah tomat dengan kualitas grade A, sedangkan diluar grade A koperasi akan memberikan pilihan kepada petani apakah akan dijual sendiri atau dijual melalui KMTP.

Analisis faktor internal dan faktor eksternal dilakukan dengan cara mengidentifikasi variabel internal dan variable eksternal yang berhubungan dengan organisasi atau perusahaan. Variabel internal adalah variabel yang berasal dari dalam Koperasi MTP yakni berupa kekuatan dan kelemahan yang dimiliki Koperasi MTP. Sedangkan variabel eksternal adalah variabel yang berasal dari luar Koperasi MTP yakni merupakan peluang dan ancaman yang dihadapi Koperasi MTP.

Analisis faktor-faktor internal bertujuan untuk mengetahui kecenderungankecenderungan dan kejadian-kejadian yang berada pada KMTP. Analisis yang dilakukan berfokus pada faktor-faktor kunci yang menjadi kekuatan dan kelemahan bagi suatu usaha, sehingga memudahkan manajemen untuk menentukan strategi-strategi dalam memanfaatkan kekuatan serta untuk mengurangi bahkan menghilangkan kelemahan. Adapun kekuatan yang dimiliki KMTP adalah : pengiriman barang tepat waktu, pengembangan program OVOP dari Kemenkop dan UKM, kelompok tani yang tersebar di Jawa Barat, pengawasan yang baik, kontrol kualitas produk berjalan baik, mempunyai mini market khusus sayuran segar, tim sdm yang profesional, memberikan insentif bagi anggota kelompok tani, kualitas produk unggulan dan jaringan pasar yang luas.

Sedangkan kelemahan yang ada pada KMTP adalah : modal kecil dan kesulitan modal dalam pengembangan usaha, sarana dan prasarana pendukung kurang memadai, kemampuan 


\section{sosio e-kons}

Volume 10, No. 1, April 2018, pp. 47-56

e-ISSN: 2502-5449

p-ISSN: 2085-2266

http://journal.lppmunindra.ac.id/index.php/sosio_ekons

manajerial pengurus kurang maksimal, kualitas sdm pengurus, pengelola dan anggota terbatas, daya saing lemah, rendahnya partisipasi anggota dalam memanfaatkan unit usaha koperasi,

saluran distribusi lambat berkembang, teknologi pertanian belum modern, promosi produk yang dilakukan belum maksimal, belum ada cabang/perwakilan koperasi.

Analisis faktor-faktor eksternal bertujuan untuk mengetahui kecenderungankecenderungan dan kejadian-kejadian yang berada di luar kendali suatu usaha. Analisis yang dilakukan berfokus pada faktor-faktor kunci yang menjadi ancaman dan peluang bagi suatu usaha, sehingga memudahkan manajemen untuk menentukan strategi-strategi dalam meraih peluang serta menghindari ancaman.

Ada pun peluang yang dimiliki KMTP adalah : adanya dukungan dari pemerintah, sejumlah swlayan menjadi mitra bisnis, Kelancaran jalur distribsi, pusat perhatian mahasiswa, akademisi dan praktisi untuk melakukan penelitian, konsumen lebih menyukai produk pertanian segar, konsumen lebih menyukai produk pertanian organik, pasar ekspor hortikultura. Sedangkan ancaman yang dihadapi oleh KMTP adalah : persaingan produk hortikultura, persaingan yang semakin ketat, penawaran kualitas produk hortikultura di pasar yang sama, tumbuhnya berbagai koperasi dengan program OVOP pada bidang agribisnis dan hortikultura, tumbuhnya produk unggulan hortikultura, semakin mudahnya akses kredit perbankan dengan bunga rendah, promosi produk dari perusahaan pesaing lebih maksimal, permainan harga dari pesaing, ekonomi nasional kurang baik.

Setiap variabel yang ada pada internal dan eksternal KMTP diberi bobot dan rating. Kemudian variabel yang telah diberi bobot dan rating tersebut dihitung nilai skore yang diperoleh dengan cara mengalikan bobot dengan ratingnya. Tebel 3 dan table 4 menunjukkan bobot, rating dan skore yang diperoleh Variabel internal KMTP dan variable eksternal KMTP, yakni kekuatan KMTP memperoleh skore 1,865, kelemahan KMTP mempunyai skore sebesar 0,899. Sedangkan variabel eksternal yakni peluang yang dimiliki KMTP mendapat skore sebesar 1,719 sedangkan ancaman yang dihadapi KMTP memiliki skore sebesar 6,803.

\section{Tabel 1. Bobot, Rating dan Skore Faktor Kekuatan KMTP}

\begin{tabular}{|c|c|c|c|c|}
\hline \multicolumn{5}{|c|}{ Faktor Internal - Kekuatan KMTP } \\
\hline No & Uraian & Bobot & Rating & Skor \\
\hline 1 & Pengiriman barang tepat waktu & 0,055 & 4 & 0,221 \\
\hline 2 & $\begin{array}{l}\text { Pengembangan program OVOP dari Kemengkop dan } \\
\text { UKM }\end{array}$ & 0,056 & 4 & 0,223 \\
\hline 3 & $\begin{array}{l}\text { Pusat Mempunyai sejumlah kelompok tani yang tersebar } \\
\text { dijawa barat }\end{array}$ & 0,051 & 3 & 0,152 \\
\hline 4 & $\begin{array}{l}\text { Mempunyai pengawasan yang baik dari dewan pengawas } \\
\text { dan dewan penasehat }\end{array}$ & 0,052 & 3 & 0,157 \\
\hline 5 & Sistem kontrol kualitas produk berjalan baik & 0,052 & 3 & 0,157 \\
\hline 6 & Membuka mini market khusus sayuran segar & 0,051 & 3 & 0,153 \\
\hline 7 & Tim SDM yang handal dan professional & 0,054 & 4 & 0,215 \\
\hline 8 & Memberikan Isentif bagi anggota kelompok tani & 0,051 & 3 & 0,154 \\
\hline 9 & Kualitas produk unggulan & 0,054 & 4 & 0,216 \\
\hline 10 & Jaringan pasar luas & 0,054 & 4 & 0,217 \\
\hline & Total Skor & & & 1,865 \\
\hline
\end{tabular}


Tabel 2. Bobot, Rating dan Skore Faktor Kelemahan KMTP

\begin{tabular}{clccc}
\hline \multicolumn{5}{c}{ Faktor Internal - Kelemahan KMTP } \\
\hline No & \multicolumn{1}{c}{ Uraian } & Bobot & Rating & Skor \\
\hline 1 & $\begin{array}{l}\text { Modal yang mampu diputar relatif kecil dan kesulitan } \\
\text { modal dalam pengembangan usaha }\end{array}$ & 0,049 & 2 & 0,099 \\
\hline & $\begin{array}{l}\text { Sarana dan prasarana pendukung kelancaran usaha } \\
\text { dari aktivitas usaha koperasi seperti sarana } \\
\text { komunikasi, transportasi, komputer dan tempat usaha } \\
\text { kurang memadai }\end{array}$ & 0,042 & 2 & 0,084 \\
\hline 3 & Kemampuan manajerial pengurus kurang maksimal \\
\hline 4 & $\begin{array}{l}\text { Kualitas SDM pengurus, pengelola dan anggota } \\
\text { terbatas }\end{array}$ & 0,040 & 1 & 0,040 \\
\hline 5 & Daya saing lemah & 0,044 & 2 & 0,088 \\
\hline 6 & $\begin{array}{l}\text { Rendahnya partisipasi anggota dalam memanfaatkan } \\
\text { unit usaha koperasi }\end{array}$ & 0,050 & 2 & 0,086 \\
\hline 7 & Saluran distribusi lambat berkembang & 0,049 & 2 & 0,099 \\
\hline 8 & Teknologi pertanian belum modern & 0,049 & 2 & 0,098 \\
\hline 9 & Promosi produk yang dilakukan belum maksimal & 0,051 & 2 & 0,102 \\
\hline 10 & Belum ada cabang koperasi MTP lain & 0,052 & 2 & 0,104 \\
\hline & $\quad$ Total Skor & & 0,899 \\
\hline
\end{tabular}

Tabel 3. Bobot, Rating dan Skore Faktor Peluang KMTP

\begin{tabular}{clccc}
\hline \multicolumn{1}{c}{ Faktor Eksternal - Peluang KMTP } & & \\
\hline No & \multicolumn{1}{c}{ Uraian } & Bobot & Rating & Skor \\
\hline 1 & $\begin{array}{l}\text { Adanya dukungan dari pemerintah (Dinas Koperasi dan } \\
\text { Kemenag Koperasi dan UKM }\end{array}$ & 0,070 & 4 & 0,279 \\
\hline 2 & Sejumlah pasar swalayan menjadi mitra bisnis & 0,068 & 4 & 0,272 \\
\hline 3 & Jalur distribusi menjadi lancer & 0,070 & 4 & 0,280 \\
\hline 4 & $\begin{array}{l}\text { Pusat perhatian mahasiswa dan kalangan akademisi dan } \\
\text { praktisi untuk melakukan penelitian }\end{array}$ & 0,070 & 4 & 0,279 \\
\hline 5 & Konsumen lebih menyukai produk pertanian segar & 0,068 & 4 & 0,272 \\
\hline 6 & Konsumen lebih menyukai produk pertanian organic & 0,062 & 3 & 0,186 \\
\hline 7 & Pasar Ekspor Hortikultura & 0,050 & 3 & 0,151 \\
\hline$\quad$ Total Skore & & & 1,719 \\
\hline
\end{tabular}

Tabel 4. Bobot, Rating dan Skore Faktor Ancaman KMTP

\begin{tabular}{|c|c|c|c|c|}
\hline \multicolumn{5}{|c|}{ Faktor Eksternal - Ancaman KMTP } \\
\hline No & Uraian & Bobot & Rating & Skor \\
\hline 1 & Persaingan produk hortikultura & 0,054 & 2 & 0,109 \\
\hline 2 & $\begin{array}{l}\text { Persaingan semakin ketat di era masyarakat ekonomi } \\
\text { asean dan globalisasi }\end{array}$ & 0,064 & 2 & 0,128 \\
\hline 3 & $\begin{array}{l}\text { Penawaran kualitas produk holtikultura dipasar yang } \\
\text { sama }\end{array}$ & 1,034 & 2 & 2,068 \\
\hline 4 & $\begin{array}{l}\text { Tumbuhnya berbagai koperasi dengan program } \\
\text { OVOP pada bidang agribisnis dan holtikultura }\end{array}$ & 1,998 & 2 & 3,997 \\
\hline 5 & Tumbuhnya produk unggulan holtikultura & 0,068 & 2 & 0,136 \\
\hline 6 & $\begin{array}{l}\text { Semakin mudahnya akses kredit perbankkan dengan } \\
\text { bunga rendah }\end{array}$ & 0,067 & 2 & 0,133 \\
\hline
\end{tabular}


Volume 10, No. 1, April 2018, pp. 47-56

e-ISSN: $2502-5449$

p-ISSN: 2085-2266

http://journal.lppmunindra.ac.id/index.php/sosio_ekons

\begin{tabular}{llccc}
\hline \hline 7 & $\begin{array}{l}\text { Promosi produk dari perusahaan pesaing lebih } \\
\text { maksimal }\end{array}$ & 0,065 & 2 & 0,130 \\
\hline 8 & Permainan harga dari pesaing & 0,053 & 1 & 0,053 \\
\hline 9 & Ekonomi nasional kurang membaik & 0,050 & 1 & 0,050 \\
\hline & Total Skor & & & 6,803 \\
\hline
\end{tabular}

Berdasarkan hasil perhitungan skore yang diperoleh, maka didapatkan kombinasi strategi kuantitatif sebagai berikut :

Tabel 5. Matriks SWOT Pendekatan Kuantitatif

\begin{tabular}{|c|c|c|}
\hline EFAS IFAS & $\begin{array}{c}\text { Kekuatan } \\
\text { (Strength) -S }\end{array}$ & $\begin{array}{c}\text { Kelemahan } \\
\text { (Weakness) - W }\end{array}$ \\
\hline $\begin{array}{l}\text { Peluang } \\
\text { (Opportunity) - O }\end{array}$ & Strategi $\mathrm{SO}=1,865+1,719=3,584$ & $\begin{array}{l}\text { Strategi } \mathrm{WO}=0,899+1,719 \\
=2,618\end{array}$ \\
\hline $\begin{array}{l}\text { Ancaman } \\
\text { (Threat) }-\mathrm{T}\end{array}$ & Strategi $\mathrm{ST}=1,865+6,803=8,668$ & $\begin{array}{l}\text { Strategi } \mathrm{WT}=0,899+6,803 \\
=7,701\end{array}$ \\
\hline
\end{tabular}

Kombinasi strategi, yang disajikan pada Tabel 7 merupakan analisis model kuantitatif perumusan strategi, yang didasarkan pada jumlah nilai skor pada masing-masing faktor yang ada pada masing-masing strategi baik itu untuk strategi SO, WO, ST, dan WT. Berdasarkan Tabel tersebut, maka KMTP sebaiknya memanfaatkan strategi ST karena mempunyai nilai skor tertinggi jika dibandingkan dengan yang lainya itu sebesar 8,668. Selanjutnya diikuti dengan strategi WT dengan nilai 7,701, SO dengan nilai 3,584, dan WO dengan nilai 2,618.

Berdasarkan hasil analisis matrik SWOT dengan analisis model kuantitatif untuk mendapatkan perumusan yang efektif, yaitu strategi ST atau strategi mobilisasi sumber daya yaitu strategi menggunakan Kekuatan (Strength) untuk menghadapi Ancaman (Threat), maka implementasi strategi ST adalah (1) Persaingan produk hortikultura dapat diatasi dengan adanya kualitas produk unggulan; (2) Persaingan semakin ketat di era masyarakat ekonomi asean dan globalisasi, dapat diatasi melalui jaringan pasar luas; (3) Penawaran kualitas produk holtikultura dipasar yang sama dapat diatasi membuka mini market khusus sayuran segar. (4) Tumbuhnya berbagai koperasi dengan program OVOP pada bidang agribisnis dan holtikultura, dapat diatasi dengan memiliki tim SDM yang handal dan professional; (5) Tumbuhnya produk unggulan holtikultura, dapat diatasi dengan sistem kontrol kualitas produk berjalan baik; (6) Semakin mudahnya akses kredit perbankkan dengan bunga rendah, dapat diatasi dengan mengembangkan program OVOP dari Kemeneg Koperasi dan UKM; (7) Promosi produk dari perusahaan pesaing lebih maksimal, dapat diatasi dengan membuka mini market khusus sayuran segar; (8) Permainan harga dari pesaing, dapat diatasi dengan mempunyai pengawasan yang baik dari dewan pengawas dan dewan penasehat; (9) Ekonomi nasional kurang membaik, dapat diatasi dengan memberikan Insentif bagi anggota KMTP.

Evaluasi faktor internal-eksternal menghasilkan profil strategi pengembangan KMTP dalam mendukung program One Village One Product (OVOP). Berdasarkan data faktor-faktor internal dan eksternal didapatkan skor pembobotan sebagai berikut : faktor kekuatan $=1,865$; faktor kelemahan $=0,899$; faktor peluang $=1,719$; faktor ancaman $=6,803$. Dari skor pembobotan tersebut, selanjutnya diplotkan pada matriks SWOT yang terdiri dari 4 kuadran, yang menyiratkan tipe strategi yang harus dijalankan. Dari perpotongan keempat garis faktor kekuatan, kelemahan, peluang dan ancaman, maka didapatkan koordinat yaitu :

$\frac{\text { Skor kekuatan - skor kelemahan }}{2}: \frac{\text { Skor Peluang-Skor ancaman }}{2}$ 


\section{sosio e-kons}

Volume 10, No. 1, April 2018, pp. 47-56

e-ISSN: 2502-5449

p-ISSN: 2085-2266

http://journal.lppmunindra.ac.id/index.php/sosio_ekons

$=\frac{1,865-0,899}{2}: \frac{1,719-6,803}{2}$

$=(0,483:-2,542)$

$=$ Berada pada kuadran II (positif, negatif)

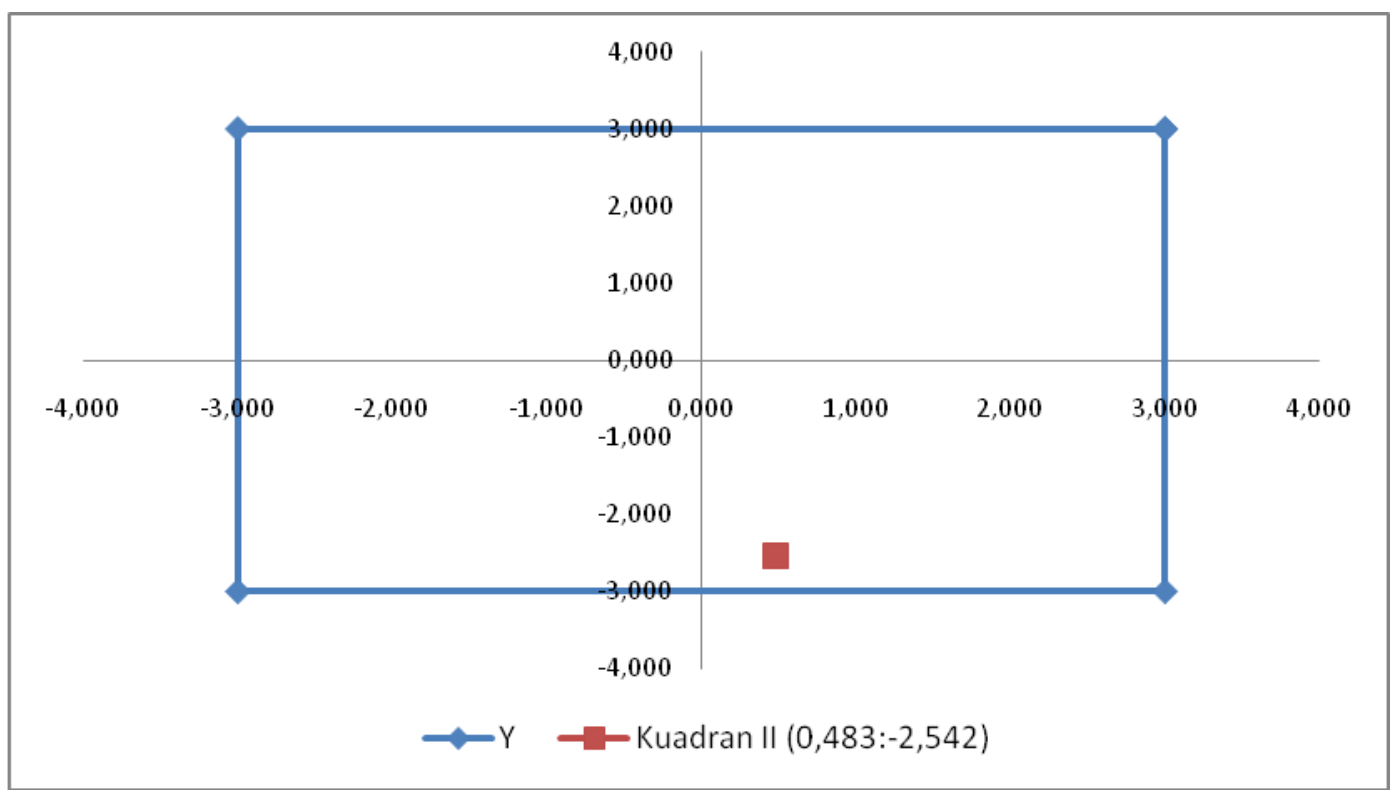

Hasil analisa diperoleh Koordinat $(0,483 ;-2,542)$, koordinat ini masuk pada kuadran II, yakni strategi diversifikasi. Posisi ini menandakan sebuah organisasi yang kuat namun menghadapi tantangan yang besar. Rekomendasi strategi yang diberikan adalah Diversifikasi Strategi, artinya organisasi dalam kondisi mantap namun menghadapi sejumlah tantangan berat sehingga diperkirakan roda organisasi akan mengalami kesulitan untuk terus berputar bila hanya bertumpu pada strategi sebelumnya. Oleh karenanya, organisasi disarankan untuk segera memperbanyak ragam strategi taktisnya

\section{SIMPULAN}

Berdasarkan pada data yang telah dikumpulkan dan pengujian yang telah dilakukan terhadap permasalahan, maka dapat diambil kesimpulan sebagai berikut : 1) Pada tahun 2008, KMTP memperoleh tugas untuk menerapkan program OVOP (One Village One Product) dari Kementrian Negara Koperasi dan UKM. Lembaga ini berhasil menempatkan posisinya dalam jalur pemasaran agribisnis dan hortikultura dengan memenuhi standar permintaan dari pihak konsumen yang menjadi target pemasarannya yakni supermarket se-Jabodetabek. 2) Berdasarkan analisa SWOT, KMTP sebaiknya memanfaatkan strategi ST atau mobilisasi sumber daya karena mempunyai nilai skor tertinggi jika dibandingkan dengan yang lainya itu sebesar 8,668. Selanjutnya diikuti dengan strategi WT dengan nilai 7,701, SO dengan nilai 3,584 , dan WO dengan nilai 2,618. Hasil analisa posisi diperoleh Koordinat $(0,483 ;-2,542)$, koordinat ini masuk pada kuadran II, yakni strategi diversifikasi. Posisi ini menandakan sebuah organisasi yang kuat namun menghadapi tantangan yang besar. Rekomendasi strategi yang diberikan adalah Diversifikasi Strategi, artinya organisasi dalam kondisi mantap namun menghadapi sejumlah tantangan berat sehingga diperkirakan roda organisasi akan mengalami kesulitan untuk terus berputar bila hanya bertumpu pada strategi sebelumnya. 


\section{SARAN}

Saran yang dapat diberikan dari penelitian ini adalah sebagai berikut: 1) Pemerintah Daerah/Dinas Koperasi dan UKM perlu bekerja sama untuk mengembangkan program OVOP di Kabupaten Cianjur. Kerja sama dapat berupa sosialisasi dan pelatihan di berbagai desa supaya gerakan OVOP dapat lebih dikenal oleh petani dan masyarakat. Dinas Koperasi dan UKM perlu melakukan evaluasi secara berkala sehingga program OVOP yang telah berjalan dapat dilaksanakan dengan lebih baik. 2) Petani perlu meningkatkan penggunaan teknologi pada subsistem hulu, onfarm, dan hilir untuk mengantisipasi dampak kekurangan tenaga kerja di sektor pertanian sehingga produktivitas usahatani dapat meningkat secara berkelanjutan dalam jangka panjang. 3) Penelitian mengenai efektivitas pelaksanaan program OVOP dan pengaruh program OVOP terhadap pemasaran produk agribisnis diperlukan untuk mengembangkan gerakan OVOP di Indonesia.

\section{DAFTAR RUJUKAN}

David, Fred R. (2008). Strategic Management : Concep and Cases, $12^{\text {th }}$ Edition, New York, Prentice Hall.

Ferrel, OC and D. Harline. (2005). Marketing Strategic. South Western, Thomson Corporation

Husodo. S.Y, dkk. (2004). Pertanian Mandiri. Jakarta: Penebar Swadaya

Jogiyanto, M. Hartono. (2005). Analisis dan Desain Sistem Informasi, Yogyakarta, Penerbit Andi

Kearns, Kevin P, (1992). From Comparative Advantage to Damage Control : Clarifying Strategic Issues Using SWOT Analysis. Journal Non Profit Management and Leadership, Volume 3 No. 1 pp. 46, Pennsylvania, Univercity of Pittsburgh

Kotler, Philip, Gary Amstrong. (2008). Prinsip-prinsip Pemasaran Jilid 1 \& 2 Edisi 12. Jakarta, Penerbit Erlangga.

Pierce, John and Richard Robinson, (1998), Strategic Management, Connecticut, Yale Univercity

Suradisastra, Kedi. (2008). Strategi Pemberdayaan Kelembagaan Petani. Pusat Analisa Sosial Ekonomi dan Kebijakan Pertanian. Bogor. Jurnal Forum Penelitian Agro Ekonomi, Volume 26 No 2 Desember 2008

Syahyuti. (2008). Kebijakan Pengembangan Gabungan Kelompok Tani (GAPOKTAN) Sebagai Kelembagaan Ekonomi di Pedesaan. Pusat Penelitian Sosial Ekonomi. Bogor

Umar, Husen. (2008). Metode Penelitian Untuk Skripsi dan Tesis Bisnis. Jakarta. Penerbit Raja Grafindo. 